\title{
Wood molasses as a preservative for high moisture barley. 2. Ration digestibility and rumen fermentation in sheep
}

\author{
PEKKA HUHTANEN \\ Department of Animal Husbandry, University of Helsinki, \\ SF-00710 HELSINKI 71, Finland
}

\begin{abstract}
The effect of wood molasses ensiled barley on ration digestibility and nitrogen utilization (Exp. 1 and Exp. 2) and on rumen fermentation and degradation rate in sacco (Exp. 2) was investigated in two experiments. The ration contained $0.9 \mathrm{~kg}$ of DM. The proportion of hay was $30 \%$ in Exp. 1 and $40 \%$ in Exp. 2. In Exp. 1 the experimental diets were dried barley (DB) and barley ensiled with a level of 8 (WMB8) or $16 \%$ (WMB16) wood molasses of barley DM. In Exp. 2 the diets were dried barley (DB), propionic acid-treated barley (PAB) and barleys ensiled with $0.3 \% \mathrm{v} / \mathrm{w} \%$ of AIV II solution (AIVB) or with wood molasses at a level of $12 \%$ of barley DM (WMB12).

The ration digestibility decreased with increasing levels of wood molasses. The difference in $\mathrm{DM}$ and organic matter $(\mathrm{OM})$ digestibility was significant $(\mathrm{P}<0.05)$ between $\mathrm{DB}$ and WMB16. Wood molasses tended to decrease the apparent digestibility of crude protein and crude fibre and to increase nitrogen retention. The percentages of nitrogen retained of ingested were in Exp. 1 on DB, WMB8 and WMB16 diets 13.1, 17.8 and $15.8 \%$ and in Exp. 2 on DB, PAB, AIVB and WMB12 diets 13.8, 13.2, 10.3 and $14.5 \%$, respectively.

After feeding, the concentration of total VFA in the rumen was higher when ensiled barleys were fed. The proportion of propionic acid in the total VFA was greater with DB and PAB than with AIVB and WMB12 diets $(\mathrm{P}<0.01)$, and butyric acid was correspondingly lower $(\mathrm{P}<0.01$ and $\mathrm{P}>0.05)$. The proportion of isovaleric and valeric acids was highest on AIVB diet. On DB and PAB diets the ammonia concentration in the rumen decreased after feeding, but on AIVB and WMB12 diets the highest value was reached 1.5 hours after feeding. The degradation rate of DM and CP as determined by nylon bag method was faster on AIVB and WMB12 than on DB and PAB diets.
\end{abstract}

\section{Introduction}

Various types of wood molasses hạe been fed to livestock, with a feeding value equal to cane molasses (Turner 1964, Al-Chalabi et al. 1974, Crawford et al. 1978). Chang et al.
(1977) found no differences in diets containing 8 and $12 \%$ of spent sulphite liquor and a control diet in beef cattle. HARTNELL and SATTER (1978) suggested that the polyphenolic fraction in wood molasses (Masonex) binds with certain proteins to decrease 
their microbiological degradation and increase the amount of dietary nitrogen that escapes the rumen fermentation.

Salo (1978) and Huhtanen (1984 a) reported wood molasses, a by-product from the wood processing industry, to be an efficient preservative for high moisture barley. The digestibility of barley ensiled with wood molasses was lower than dried barley in pigs (Huhtanen 1984 a) and in the diet of pigs 10-20\% wood molasses decreased the ration digestibility (Näsı 1984).

The objective of the present study was to investigate the effects of wood molasses ensiled barley on ration digestibility, nitrogen utilization and rumen fermentation in sheep and to evaluate the optimum level of wood molasses in ensiled barley as an energy source for ruminants. The wood molasses ensiled barleys were the same used in the previous experiment (HuHTANEN 1984 a).

\section{Material and methods}

The digestibility and rumen fermentation trials were performed with three (Exp. 1) and four (Exp. 2) Finnsheep rams in $3 \times 3$ and $4 \times 4$ Latin square arrangements. The average weight of the sheep was $48 \mathrm{~kg}$ in Exp. 1 and $55 \mathrm{~kg}$ in Exp. 2. The trials consisted of transition, standardization and collection periods lasting 5, 9 and 7 days each.

The sheep were kept in metabolism cages allowing a separate collection of faeces and urine. During the collection periods the sheep were provided with faeces-collecting harnesses.

In Exp. 1, diets comprised $300 \mathrm{~g}$ of hay and either $700 \mathrm{~g}$ of dried barley (DB) or an equal amount of DM of barley ensiled with wood molasses at a level of 8 (WMB8) or $16 \%$ (WMB16) of barley DM; in Exp. 2 diets comprised $400 \mathrm{~g}$ of hay and $480 \mathrm{~g} \mathrm{DM}$ of dried barley (DB), propionic acid-treated barley (PAB), barley ensiled with $0.3 \% \mathrm{v} / \mathrm{w}$ of AIV II solution (AIVB) or barley ensiled with wood molasses at a level of $12 \%$ barley DM (WMB12). In addition the animals re- ceived a mineral mixture ad libitum in Exp. 1 and $20 \mathrm{~g} / \mathrm{d}$ in Exp. 2. Water was given freely and its consumption was measured during the collection periods. Feeding took place twice daily. The sheep were weighed before and after the collection periods.

The faeces and urine were collected in the morning and representative samples were taken for analysis and stored frozen until analyzed. DM determinations were made at $103^{\circ} \mathrm{C}$; the samples for analysis were dried in vacuum at $50^{\circ} \mathrm{C}$ for $2-3$ days and milled through a $1-\mathrm{mm}$ screen. The DM contents of ensiled barleys were corrected according to Jarl and Helleday (1948). The feed analyses were made according to standard procedures and VFA determinations by the method of Huida (1973).

During the two last days of collection periods in Exp. 2, rumen samples were taken through the fistula before and 1.5, 3, 4.5 and 6 hours after the morning feeding. pH-measurements were made immediately. The samples were centrifuged for $10 \mathrm{~min}$ at 2000 rpm. Ammonia $\mathrm{N}$ and VFA determinations were made on the supernatant by the methods of McCullough (1967) and HuidA (1973). Samples for determination of rumen microbiota were taken 6 hours after feeding. Five $\mathrm{ml}$ of rumen content was transferred to a glass bottle containing $45 \mathrm{ml}$ of $10 \%$ formalin. The total number of protozoa was calculated according to WESTERLING (1970) and the number of bacteria using a counting chamber of dimensions $1 \times 1 \mathrm{~mm}$ and 0.2 $\mathrm{mm}$ depth. Four preparations were made of each sample for count.

The DM and crude protein (CP) degradabilities of DB, PAB, AIVB and WMB12 were determined in Exp. 2 by the method of Setälä (1983). The experimental design was $4 \times 4$ Latin square and the incubation times were 2, 5, 9 and 24 hours. The degradability measurements were performed on the same barley fed in the diets.

The results were tested by analysis of variance and the differences between the means by the Tukey-test. 


\section{Results and discussion}

Digestibility of rations

The chemical composition of the experimental feeds is presented in Table 1. Wood molasses used at levels of 12 and $16 \%$ decreased the digestibility of the ration (Table 2). The differences in the DM and OM digestibilities of DB and WMB16 were significant $(\mathrm{P}<0.05)$. Also, the $\mathrm{CP}$ and crude fibre digestibilities tended to decrease with increasing levels of wood molasses. Ammonium spent sulphite liquor (SALO and PuUMALA 1978) and spent sulphite liquor (CHANG et al. 1977), which contain more lignosulphonates than wood molasses have been found to decrease the digestibility of forages and soyabean-alfalfa substrate in vitro. In contrast, relative to cane molasses wood molasses (Masonex) has been found to have positive effect on cellulose digestibility in steers (CRAwFOrd et al. 1978). The wood molasses used in the present experiment contains, however, more lignosulphonates than Masonex.

The effects of the various preserving methods on the ration digestibility agree with the results of WeisSBACH and SCHADEREIT (1968), KORHONEN et al. (1973) and Ingalls et al. (1974). In contrast, Clark and Harsberger (1972) obtained higher DM and OM digestibilities on high moisture ensiled corn diet than on dried corn diet. McKNIGHT et al.

Table 1. Chemical composition of experimental feeds

\begin{tabular}{|c|c|c|c|c|c|c|c|c|c|}
\hline & \multicolumn{4}{|c|}{ Exp. 1} & \multicolumn{5}{|c|}{ Exp. 2} \\
\hline & Hay & DB & WMB8 & WMB16 & Hay & DB & PAB & AIVB & WMB12 \\
\hline $\begin{array}{l}\text { Dry matter, } \% \\
\text { In dry matter, } \%\end{array}$ & 84.5 & 87.5 & 57.2 & 56.0 & 80.9 & 87.0 & 83.0 & 55.0 & 54.9 \\
\hline Ash & 7.7 & 3.0 & 4.0 & 5.2 & 5.9 & 2.7 & 2.8 & 3.2 & 3.5 \\
\hline Crude protein & 10.2 & 11.8 & 12.1 & 11.0 & 8.9 & 11.6 & 13.7 & 12.7 & 12.1 \\
\hline Ether extract & 1.7 & 2.2 & 2.6 & 2.3 & 2.2 & 2.3 & 2.5 & 2.8 & 2.7 \\
\hline Crude fibre & 35.8 & 6.0 & 5.5 & 5.3 & 33.5 & 5.2 & 5.6 & 5.7 & 5.5 \\
\hline NFE & 44.6 & 77.0 & 75.8 & 76.2 & 49.6 & 78.3 & 75.5 & 75.6 & 76.2 \\
\hline
\end{tabular}

Table 2. Digestibility coefficients of total ration

\begin{tabular}{|c|c|c|c|c|c|c|c|c|}
\hline \multirow[t]{2}{*}{ Exp. 1} & \multicolumn{2}{|c|}{ DB } & & \multicolumn{2}{|c|}{ WMB8 } & & \multicolumn{2}{|c|}{ WMB16 } \\
\hline & $\bar{x}$ & s.d & & $\bar{x}$ & s.d. & & $\overline{\mathbf{x}}$ & s.d. \\
\hline Dry matter & $71.5^{a}$ & 3.1 & & $70.7^{\mathrm{ab}}$ & 2.0 & & $68.3^{b}$ & 2.6 \\
\hline Organic matter & $73.5^{a}$ & 3.0 & & $72.8^{\mathrm{ab}}$ & 2.0 & & $70.4^{b}$ & 2.3 \\
\hline Crude protein & 68.1 & 2.3 & & 67.8 & 2.1 & & 63.1 & 2.3 \\
\hline Ether extract & 70.3 & 4.1 & & 77.9 & 1.9 & & 78.3 & 1.0 \\
\hline Crude fibre & 51.1 & 6.2 & & 46.3 & 4.9 & & 42.3 & 6.0 \\
\hline NFE & 79.6 & 2.5 & & 79.1 & 1.3 & & 77.3 & 1.7 \\
\hline \multirow[t]{2}{*}{ Exp. 2} & \multicolumn{2}{|c|}{ DB } & \multicolumn{2}{|c|}{ PAB } & \multicolumn{2}{|c|}{ AIVB } & \multicolumn{2}{|c|}{ WMB12 } \\
\hline & $\bar{x}$ & s.d. & $\overline{\mathrm{x}}$ & s.d. & $\overline{\mathrm{x}}$ & s.d. & $\bar{x}$ & s.d. \\
\hline Dry matter & 71.3 & 2.3 & 72.1 & 3.2 & 71.9 & 0.4 & 69.8 & 2.2 \\
\hline Organic matter & 73.2 & 2.2 & 74.1 & 3.1 & 73.7 & 0.5 & 72.0 & 2.0 \\
\hline Crude protein & 67.4 & 1.9 & 73.0 & 2.4 & 69.8 & 3.0 & 68.4 & 4.4 \\
\hline Ether extract & 72.9 & 3.4 & 75.2 & 1.0 & 76.8 & 4.6 & 76.7 & 5.0 \\
\hline Crude fibre & 49.5 & 2.9 & 50.5 & 6.5 & 51.7 & 1.5 & 48.1 & 3.8 \\
\hline NFE & 80.0 & 2.1 & 80.2 & 2.8 & 80.0 & 0.6 & 78.5 & 1.9 \\
\hline
\end{tabular}

Means with different letters were significantly different: $a, b(P<0.05)$ 
(1973) reported greater ruminal digestion of DM, OM and starch for ensiled and acidtreated corn diets than for dried corn diet and this resulted in slightly better overall digestibility of energy and DM. Likewise GALYEAN et al. (1976) found better ruminal starch digestion on ensiled corn than on dried corn diet, but DM or OM digestion in the rumen were not affected by the preserving method. The explanation for the higher apparent CP digestibility of PAB in Exp. 2 could be the higher $\mathrm{CP}$ content of PAB.

\section{Rumen fermentation}

There were no significant differences in the average $\mathrm{pH}$-values or total VFA concentrations in the rumen (Table 3). At 1.5 and 3 hours after feeding, rumen $\mathrm{pH}$ was lower and VFA concentration higher on the ensiled barley diets than on $\mathrm{DB}$ or PAB diets (Fig. 1). Similar effects of ensiled grain on fermentation rate in the rumen have reported by Torry and Perry (1974), Prigge et al. (1976) and GALYEAN et al. (1976) in vivo and Danley and Vetter (1974) and Galyean et al. (1976) in vitro.
The proportion of acetic acid was lower on the PAB diet than on the other diets. The difference was significant $(\mathrm{P}<0.05)$ between PAB and AIVB. Molar per cent of propionic acid was higher $(\mathrm{P}<0.01)$ on DP and PAB diets than on ensiled barley diets, and molar per cent of butyric acid lower $(\mathrm{P}<0.05)$ on DB than on AIVB or WMB12 diets. Similar changes in VFA ratios when ensiled grain is used have been reported by Pratt and Conrad (1970), Ingalls et al. (1974) and Tonrey and Perry (1974). GALYEAN et al. (1976), in contrast, reported a lower acetate-propionate ratio when ensiled corn was fed to steers instead of dried corn. The slightly lower acetate-propionate ratio on the PAB diet than on the DB diet agrees with the results of CLARK et al. (1973) and may be due to the prior treatment of barley with propionic acid.

The high proportion of butyric acid on ensiled barley diets may partly be explained by higher sugar content of ensiled barley than of dried barley. Increased levels of molasses in the diet have been found to promote butyrate production (KARALAzos and SwaN

Table 3. Rumen pH, ammonia N, VFA and microbes on experimental diets. The values are averages of samples taken at different times.

\begin{tabular}{|c|c|c|c|c|c|c|c|c|}
\hline & \multicolumn{2}{|c|}{ DB } & \multicolumn{2}{|c|}{ PAB } & \multicolumn{2}{|c|}{ AIVB } & \multicolumn{2}{|c|}{ WMB12 } \\
\hline & $\overline{\mathrm{x}}$ & s.d. & $\overline{\mathrm{x}}$ & s.d. & $\overline{\mathbf{x}}$ & s.d. & $\bar{x}$. & s.d. \\
\hline $\mathrm{pH}$ & 5.97 & 0.32 & 5.97 & 0.31 & 5.90 & 0.36 & 5.86 & 0.28 \\
\hline Ammonia $\mathrm{N} \mathrm{mmol/1}$ & $8.1^{\mathrm{a}}$ & 5.2 & $12.3^{\mathrm{ab}}$ & 2.6 & $11.1^{\mathrm{ab}}$ & 3.9 & $12.7^{b}$ & 5.9 \\
\hline Total VFA mmol/1 & 81.2 & 10.0 & 79.7 & 6.5 & 82.5 & 13.9 & 85.3 & 11.3 \\
\hline \multicolumn{9}{|l|}{ Molar per cent of } \\
\hline Acetic acid & $59.4^{\mathrm{ab}}$ & 1.8 & $57.1^{b}$ & 2.1 & $60.2^{\mathrm{a}}$ & 2.9 & $59.1^{\mathrm{ab}}$ & 4.6 \\
\hline Propionic acid & $25.9^{d}$ & 3.1 & $26.6^{d}$ & 3.3 & $20.7^{e}$ & 3.2 & $22.2^{e}$ & 2.5 \\
\hline Butyric acid & $11.0^{\circ}$ & 3.0 & $13.0^{\mathrm{de}}$ & 1.8 & $14.1^{d}$ & 2.0 & $14.7^{d}$ & 2.4 \\
\hline Isovaleric acid & $2.3^{\mathrm{d}}$ & 0.7 & $1.8^{\mathrm{d}}$ & 0.4 & $2.9^{e}$ & 1.0 & $2.1^{\mathrm{d}}$ & 0.3 \\
\hline Valeric acid & $1.3^{\mathrm{d}}$ & 0.3 & $1.5^{\mathrm{de}}$ & 0.2 & $2.0^{f}$ & 0.7 & $1.7^{\mathrm{ef}}$ & 0.5 \\
\hline Caproic acid & $0.0^{\mathrm{a}}$ & 0.0 & $0.0^{\mathrm{a}}$ & 0.0 & $0.1^{\mathrm{ab}}$ & 0.1 & $0.2^{\mathrm{b}}$ & 0.2 \\
\hline Ratio A:P & $2.3^{e f}$ & 0.3 & $2.2^{f}$ & 0.4 & $3.0^{\mathrm{d}}$ & 0.5 & $2.7^{\mathrm{de}}$ & 0.5 \\
\hline Ratio A:B & $5.9^{\mathrm{d}}$ & 2.1 & $4.5^{\mathrm{de}}$ & 0.7 & $4.4^{d e}$ & 0.8 & $4.2^{e}$ & 1.1 \\
\hline Ratio P:B & $2.6^{a}$ & 1.0 & $2.1^{\mathrm{ab}}$ & 0.5 & $1.9^{\mathrm{b}}$ & 0.9 & $1.8^{\mathrm{b}}$ & 0.6 \\
\hline Bacteria $\mathrm{n} \times 10^{9}$ ) & $4.67^{\mathrm{a}}$ & & $4.00^{\mathrm{ab}}$ & & $2.84^{a b}$ & & $2.16^{b}$ & \\
\hline Protozoa $\mathrm{n} \times 10^{4} 1$ ) & 87.4 & & 115.2 & & 114.9 & & 90.3 & \\
\hline
\end{tabular}

1) 6 hours after feeding

Means with different letters significantly different: $a, b, c(P<0.05), c, d, f(P<0.01)$ 

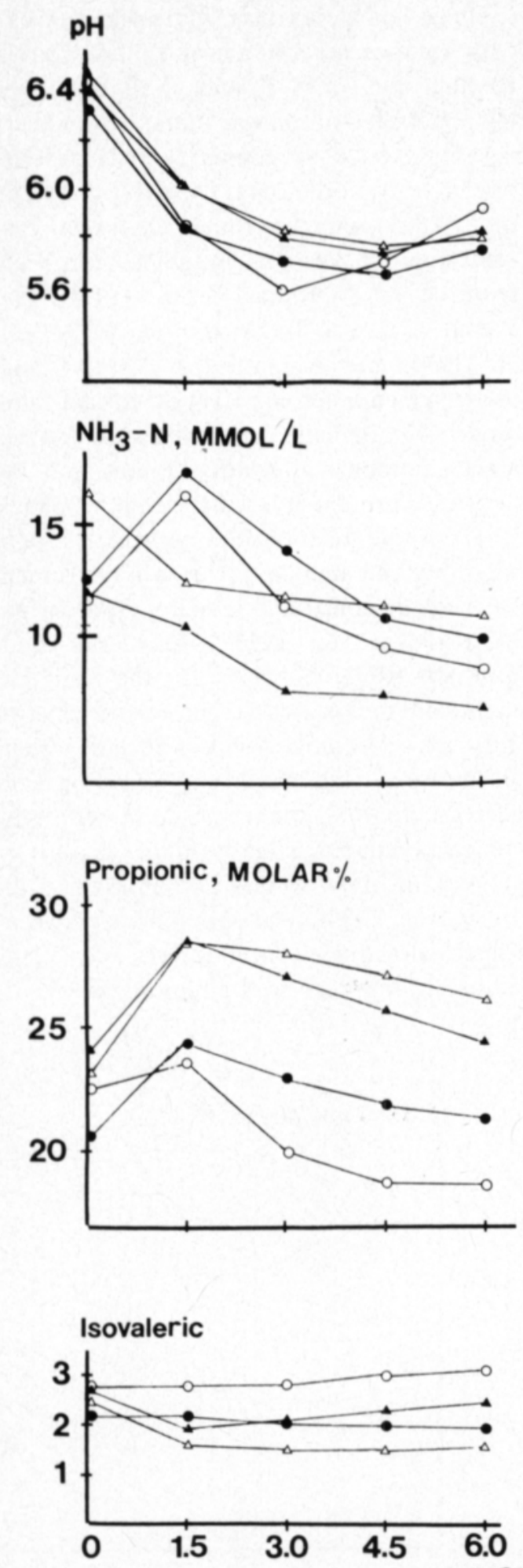
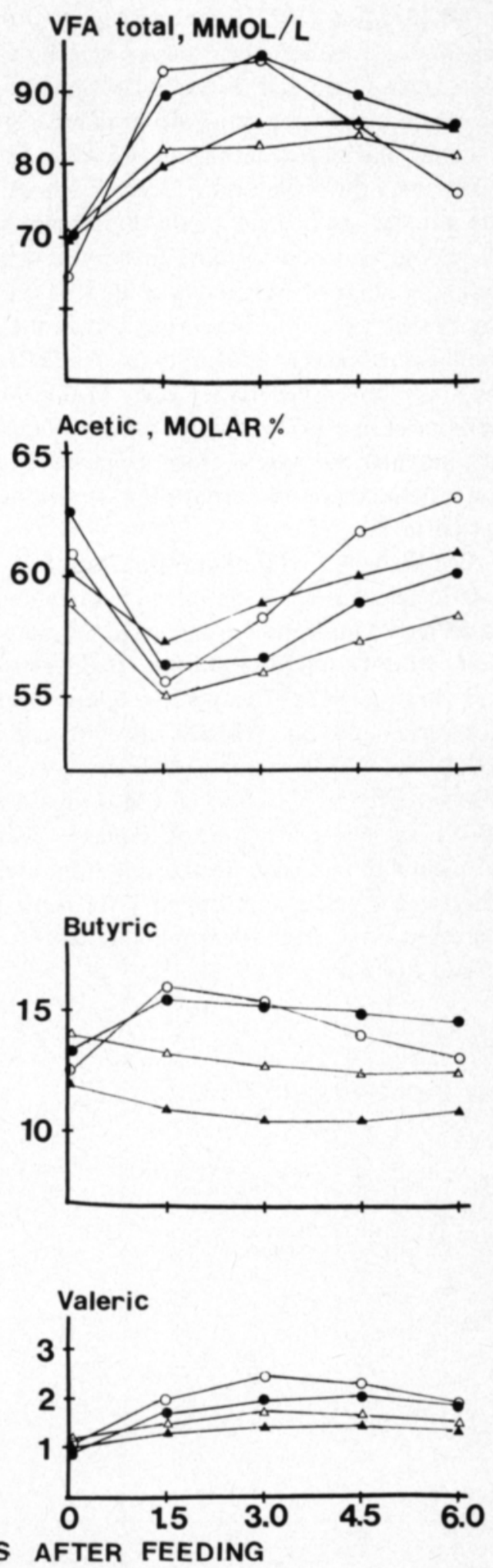

Fig. 1. Rumen $\mathrm{pH}$, ammonia $\mathrm{N}$ and VFA of sheep fed with different barleys ( $\boldsymbol{\Delta} \mathrm{DB}, \triangle \mathrm{PAB}, \bigcirc \mathrm{AIVB}$ and - WMB12) 
1974). SyrJäLÄ (1972) reported higher proportion of butyrate when sucrose was added to a grass silage diet instead of starch. But also a change in the ratio of the number of bacteria and protozoa has an effect on the propionate-butyrate ratio. Increases in ciliate number are proportionate to decrease in propionic acid and increase in butyric acid (EAdie et al. 1970, Whitelaw et al. 1972). In the present experiment the ratio between the number of bacteria and protozoa tended to be lower on ensiled barley diets (Table 3). ISHAQUE et al. (1971) reported that a change in fermentation pattern from propionate to butyrate increases the proportion of OM digested in the rumen.

The higher $(\mathrm{P}<0.01)$ proportion of isovaleric acid on AIVB diet may be attributed to decreased utilization or increased deamination by rumen micro-organisms (BRÜGGEMAN and GIESEKE 1967). The lower proportion of isovaleric acid on WMB12 diet than on AIVB diet is in agreement with in vitro results reported by Chalupa and Montgomery (1979). At lower levels wood molasses was fermented to methane, acetate and butyrate, whereas increased supplement level caused increased production of propionate (CHALUPA and MONTGOMERY 1979).

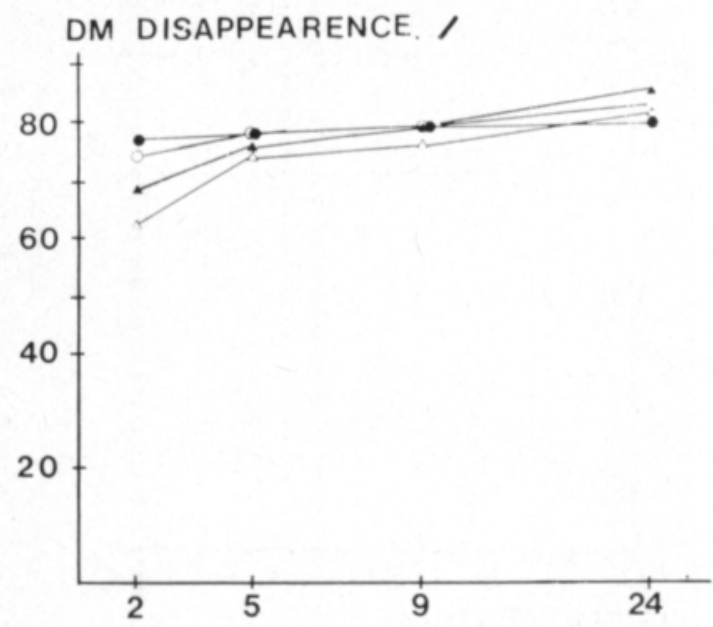

On ensiled barley diets, rumen ammonia $\mathrm{N}$ concentration reached a peak 1.5 hours after feeding, but on DB and PAB diets the highest concentration was found before feeding. On average, ammonia $\mathrm{N}$ concentration was higher $(\mathrm{P}<0.05)$ on WMB12 diet than on DB diet. A higher rumen ammonia concentration with ensiled grains has also been reported by McKNIGHT et al. (1973) and Prigge et al. (1978). In contrast, Ingalls et al. (1974) and Prigge et al. (1976) found lower rumen ammonia level on ensiled than on dried grain diets. One explanation for the higher ammonia level after feeding may be increased protein solubility during ensiling. The positive relationship between protein solubility and ammonia release in the rumen has been demonstrated in many experiments (ANNISON et al. 1956, Donaldson and EDWARDS 1977). A reason for the different shapes of ammonia curves may be the change in rumen microbiota. It has been shown that an increase in the number of protozoa and decrease in the number bacteria increases rumen ammonia concentration (KLOPFENStein et al. 1966 Males and Purser 1970, VeIRA et al. 1983). The correlations between rumen ammonia concentration and VFA ratios in the rumen were in good agreement

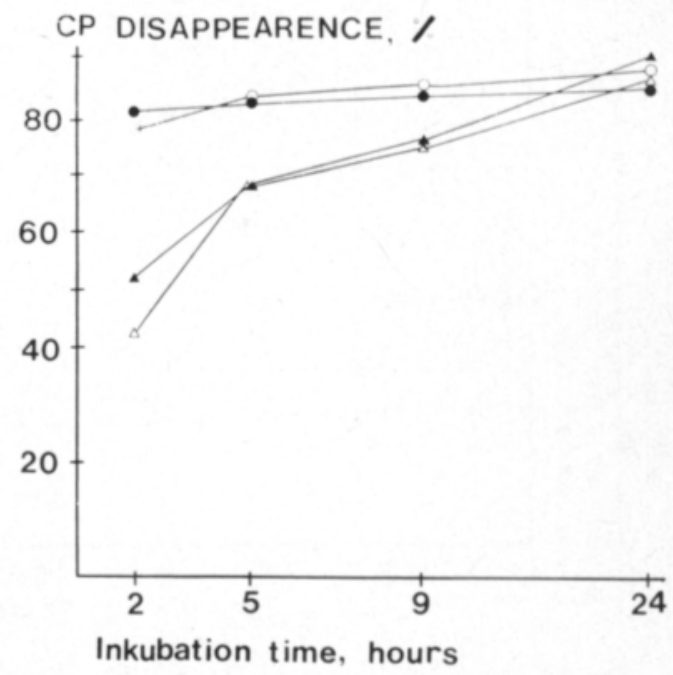

Fig. 2. DM and CP disappearance of different barleys in the rumen ( $\mathbf{\Delta}$ DB, $\triangle$ PAB, $\bigcirc$ AIVB and $\bullet$ WMB12) 
with those observed by Males and Purser (1970).

\section{Degradability of DM and CP}

$\mathrm{DM}$ and $\mathrm{CP}$ degradation rates in the rumen were faster for ensiled barleys than for DB and PAB (Fig. 2) which is in agreement with the rumen fermentation studies and in sacco studies by GALYEAN et al. (1977) with ensiled corn. The difference in the degradation rates of $\mathrm{DM}$ and $\mathrm{CP}$ decreased with longer incubation times, and after an incubation time of 24 hours the DM degradability of DB was higher $(\mathrm{P}<0.05)$ than to WMB12. Dried barley had a slower degradation rate than reported earlier by SETÄLÄ (1983) and the values were more similar to those reported by LINDBERG and VARVIKKO (1982).

\section{Nitrogen utilization}

In Exp. 1 the use of wood molasses as a preservative tended to increase nitrogen retention in sheep aged $8-10$ months, compared with DB (Table 4). The excretion of nitrogen in urine was lower $(\mathrm{P}<0.05)$ and in faeces higher $(\mathrm{P}<0.05)$ on WMB16 than on DB diet. Blood urea $\mathrm{N}$ was not determined, but was lower $(\mathrm{P}<0.01)$ in growing bulls fed on WMB12 diet than in bulls fed on AIVB diet (Huhtanen 1984 b). A reason for the slightly better protein utilization on WMB diets is suggested by the finding that xylose is a better energy source for microbial protein synthesis in vitro than sucrose or mannose (Henderickx and MarTin 1963).

The increased protein solubility of the ensiled barleys had no adverse effect on protein utilization. After feeding of ensiled barley diets microbes had more rapidly fermenting organic matter available to use soluble nitrogen for protein synthesis. Generally, proteins of low solubility are used more efficiently than proteins of high solubility because more dietary protein reaches the duodenum intact and less cycles through the process of degradation to ammonia. However, PrIGGE et al. (1976) observed greater nitrogen retention with high moisture ensiled corn than with dried rolled corn. Prigge et al. (1978) reported abomasal nitrogen flow and efficiency of microbial synthesis to be greater on ensiled or acid-treated corn than on dried corn. The increased microbial synthesis was related to increased rumen turnover rate. Increased rumen dilution rate has been found to be associated with increased acetate and butyrate and decreased propionate in rumen VFA (THOMSON et al. 1975, Owens and IsAacson 1977). This effect was also found on the ensiled barley diets of the present study.

When dietary protein is of poor quality, utilization can be improved by rumen degradation and conversion to microbial protein (Little et al. 1963, Prigge et al. 1976). Moreover, when the grain protein is protected against microbial degradation in the rumen, no positive effect on protein utiliza-

Table 4. Nitrogen balance and excretion of nitrogen in faeces and urine.

\begin{tabular}{|c|c|c|c|c|c|c|c|}
\hline & \multicolumn{3}{|c|}{ Exp. 1} & \multicolumn{4}{|c|}{ Exp. 2} \\
\hline & DB & WMB8 & WMB16 & DB & PAB & AIVB & WMB12 \\
\hline $\mathrm{N}$ intake, $\mathrm{g} / \mathrm{d}$ & 15.7 & 16.3 & 15.0 & $13.5^{\mathrm{a}}$ & $15.4^{b}$ & $14.8^{\mathrm{ab}}$ & $13.7^{\mathrm{a}}$ \\
\hline $\mathrm{N}$ in faeces, $\mathrm{g} / \mathrm{d}$ & $5.0^{2}$ & $5.3^{\mathrm{ab}}$ & $5.5^{b}$ & 4.4 & 4.2 & 4.5 & 4.3 \\
\hline $\mathrm{N}$ in urine, $\mathrm{g} / \mathrm{d}$ & $8.8^{a}$ & $8.1^{\mathrm{ab}}$ & $7.1^{\mathrm{b}}$ & 7.2 & 9.2 & 8.9 & 7.4 \\
\hline $\mathrm{N}$ balance, $\mathrm{g} / \mathrm{d}$ & 2.1 & 2.9 & 2.6 & 1.9 & 2.0 & 1.5 & 2.0 \\
\hline$\%$ of intake & 13.1 & 17.8 & 15.8 & 13.8 & 13.2 & 10.3 & 14.5 \\
\hline$\%$ of absorbed & 19.6 . & 26.4 & 25.3 & 20.6 & 18.2 & 14.6 & 20.4 \\
\hline
\end{tabular}

Means with different letters significantly different: $a, b(P<0.05)$ 
tion is found (DAvis and FaICHNEY 1973, THORNTON et al. 1977). In contrast to the results of Hartnell and Satter (1978), in the present experiment wood molasses did not slow the degradation of protein by rumen microbes. But it did decrease the breakdown of barley protein in the silo compared with AIV II solution (HuHTANEN 1984 a).

When wood molasses was used as a preservative for high moisture barley at a level of
$8-12 \%$ of barley DM, no significant effect on ration digestibility was found and it tended to improve protein utilization. Wood molasses at this level can therefore serve as an energy source as well as a preservative for grain.

Acknowledgements. I wish to express my thanks to Mr. Matti Järvi for taking care of the animals and for technical help.

\section{References}

Al-Chalabi, K., Scheider, W., Lantzschand, K.H. \& MENKE, K.H. 1774. Futterwert von Holzzuckermelasse in Rationen für Schafe, Schweine und Mastküken Lantwirtsch. Forsch. 27: 1-7.

ANNISON, E.F. 1956. Nitrogen metabolism in the rumen. Biochem. J. 64: 705-714.

Broggeman, J. \& Gieseke, D. 1967. The effect of urea on rumen microbiology and metabolism. Urea as a protein supplement. Ed. Briggs, M.H. p. 125-154. Pergamon Press.

Chalupa, W. \& Montgomery, A. 1979. Fermeability of Masonex and cane molasses. J. Anim. Sci. 48: 393400.

Chang, F.S., Dryer, I.A. \& Johnson, R.J. 1977. Performance of feedlot cattle and rumen micro-organisms as influenced by lignosulphonates J. Anim. Sci. 46: $878-884$.

Clark, J.H. \& Harsberger K.E. 1972. High moisture corn versus dry corn in combination with either corn silage or hay for lactating cows. J. Dairy Sci. 55: 1474-1480.

-, Frobish, R.A., Harsberger, K.E. \& Derring, R.G. 1973. Feeding value of dry, ensiled high moisture corn and acid treated high moisture corn fed with hay or haylage for lactating dairy cows. J. Dairy Sci. 56: 1531-1539.

Crawford, D.F., Anthony, W.B. \& Harris, R.R. 1978. Evaluation of concentrated hemicellulose extract as cattle feed. J. Anim. Sci. 46: 32-40.

Danley, M.M. \& Vetter, R.L. 1974. Artificially altered corn grain harvested at three different moisture levels. III. In vitro utilization of carbohydrate and nitrogen fractions. J. Anim. Sci. 38: 490-436.

Davis, H., Lloyd \& Faichney, G.J. 1973. The effect of formaldehyde treatment of barley on productive performance of Friesian steers. Aust. J. Exp. Agric. Anim. Husb. 13: 142-145.
Donaldson, E. \& Edwards, R.A. 1977. Feeding value of silage made using formic acid, formaldehyde and propionic acid. Anim. Prod. 25: 71-81.

Eadie, M.J., Hyldgaard-Jensen, J., Mann, S.O., Reid, R.S. \& Whitelaw, F.G. 1970. Observations on the microbiology and biochemistry of the rumen of cattle given different qualities of a pelleted barley rations. Br. J. Nutr. 27: 157-177.

Galyean, M.L., Wagner, D.G. \& Johnson, R.R. 1976. Site and extent of starch digestion in steers fed processed corn rations. J. Anim. Sci. 43: 1089-1094.

-, Wagner, D.G. \& Owens, F.N. 1977. Nylon bag dry matter digestion of corn as influenced by particle size, steam flaking and high moisture processing. Anim. Sci. Res. Rep. Okla. Agric. Exp. Sta. MP-101: $70-75$.

Hartnell, G.F. \& Satter, L.D. 1978. Effect of Masonex (hemicellulose extract) on protein degradation by rumen micro-organisms in vitro and in vivo. J. Anim. Sci. 47: 935-943.

Henderickx, H.K. \& Martin, J. 1963. In vitro study of nitrogen metabolism in the rumen: Comp. Ren. Rech. Inst. Rech. Sci. Agr. 31. 110 p. Brussels.

Huhtanen, P. 1984 a. Wood molasses as a preservative for high moisture barley. 1. Preservation and digestibility in pig. J. Agric. Sci. Finl. 56: 255-263.

-1984 b. 3. Feeding value for growing cattle. J. Agric. Sci. Finl. 56: 275-282.

HuIDA, L. 1973. Haihtuvien rasvahappojen kvantitatiivinen määrittäminen pötsinesteestä. J. Scient. Agric. Soc. Finl. 45: 483-488.

Ingalls, J.R., Clark, K.W. \& Sharma, H.R. 1974. Acid-treated high moisture barley for dairy cows. Can. J. Anim. Sci. 54: 205-209.

Ishaque, M., Thomas, P.C. \& Rook, J.A.F. 1971. Consequences to the host changes in rumen microbiological activity. Nature 231: 253-256. 
JARL, F. \& Helleday, T. 1948. Ensileringsförsők ut utfodringsförsők med ensilage. II Stat. Husd. Förs. Medd. 37: 1-63.

Karalazos, A. \& Swan, H. 1976. Molasses and its byproducts. Feed energy resources for livestock. Ed. Swan, H. \& Lewis, D. p. 29-46. Butterworths.

Klopfenstein, T.J., Purser, D.B. \& TyzniK, W.J. 1966. Effects of defaunation on feed digestibility, rumen metabolism and blood metabolites. J. Anim. Sci. 25: $765-773$

Korhonen, I., Poutiainen, E., Tuori, M. \& Lampila, M. 1973. Eri menetelmillä tuoreena săilötty ohra lihanautojen rehuna. 2. Prop-corn-ohra ja muurahaishapolla märkäsäilötty ohra lihanautojen ruokinnassa. Kehittyvä Maatalous 15: 32-41.

LindBerg, J.E. \& VARVikKo, T. 1982. Effect of bag pore size on the ruminal degradation of dry matter, nitrogenous compounds and cell wall in nylon bags. Swed. J. agric. Res. 12: 163-171.

Little, C.O., Burroughs, W. \& Woods, W. 1963. Nutritional significance of soluble nitrogen in dietary protein for ruminants. J. Anim. Sci. 22: 358-363.

Males, J.R. \& Purser, D.B. 1970. Relationship between rumen ammonia levels and the microbial population and volatile fatty acid proportion in faunated and defaunated sheep. Appl. Microb. 19: 485490.

McCullough, H. 1967. The determination of ammonia in whole blood by a direct colorimetric method. Clin. Chem. Acta 17: 297-309.

McKnight, D.R., Macleod, G.K., Buchanan-Smith, J.G. \& Movat, D.N. 1973. Utilization of ensiled, or acid-treated high moisture corn by cattle. Can. J. Anim. Sci. 53: 491-496.

NÁsı, M. 1984. Trămelass som svinforder. NJF Seminarium Nr. 57. 29.-30. 3. 1984. Stenhamra. Sverige.

OWEns, F.N. \& IsAacson, H.R. 1977. Ruminal microbial yields: Factors influencing synthesis and bypass. Fed. Proc. 36: 198-202.

PRATt, A.D. \& Conrad, H.R. 1970. Effects of ground ear corn vs. ear corn silage, on rumen fatty acid content. Ohio Agric. Res. Dev. Center. Circular 183: $1-8$.

Prigge, E.C., Johnson, R.R., Owens, F.N. \& WIL-
LIAMS, D.E. 1976. Utilization of nitrogen from ground high moisture and dry corn by ruminants. $\mathrm{J}$. Anim. Sci. 43: 705-711.

- , Galyean, M.L., Owens, F.N., Wagner, D.G. \& JoHnson, R.R. 1978. Microbial protein synthesis in steers fed processed corn rations. J. Anim. Sci. 46: 249-254.

SALo, M-L. 1978. Puumelassi tuoreviljan săilöntäaineena. J. Scient. Agric. Soc. Finl. 50: 206-211.

— \& Puumala, L. 1978. Nutritive evaluation of spent sulphite liquors. Acta Agric. Scand. 28: 298-302.

SETÁLÃ, J. 1983. The nylon bag technique in the determination of ruminal feed protein degradation. J. Scient. Agric. Soc. Finl. 55: 1-78.

SYruÃLĀ, L. 1972. Effect of different sucrose, starch and cellulose supplemerts on the utilization of grass silage by ruminants. Acta Agric. Fenn. 11: 199-276.

Thomson, D.J., Beever, D.E., Mundell, M.L., ElderField, M.L. \& Harrison, D.G. 1975. The effect of dilution rate on the pattern of fermentation in the rumen. Proc. Nutr. Soc. 34: 111A-112A.

Tonrey, R.B. \& Perry, T.W. 1974. Effect of corn preservation treatments on in vitro digestibility, ruminal $\mathrm{pH}$ and acid fermentation. J. Anim. Sci. 38: 676680.

TURner, D.M. 1964. Feed molasses from Masonite process. Forest Prod. J. 14: 282-285.

Veira, D.M., Ivan, M. \& JuI, P.Y. 1983. Rumen ciliate protozoa: effects on digestion in the stomach of sheep. J. Anim. Sci. 66: 1015-1022.

Weissbach, F. \& Schadereit, R. 1968, Untersuchungen zur Konservierung von Feuchtgetreide durch Silierung. 2. Mitteilung. Verdauungsversuche mit Silagen aus Feuchtgetreide. Arch. Tierernăhr. 18: 61-67.

Westerling, B. 1970. Rumen ciliate fauna of semidomesticated reindeer (Rangeifer tarandus L.) in Finland: Composition, volume and some seasonal variations. Acta Zoolog. Finl. 127: 1-76.

Whitelaw, F.G., Eadie, M., Mann, S.O. \& Reid, R.S. 1972. Some effects of rumen ciliate protozoa in cattle given restricted amounts of barley diet. Br. J. Nutr. 27: $425-437$.

Ms received October 12, 1984 


\section{SELOSTUS}

\section{Puumelassi tuoreen ohran säilöntäaineena.}

2. Vaikutus rehun sulavuuteen ja pötsi-

\section{fermentaatioon lampaalla}

\section{Pekka Huhtanen}

Helsingin yliopisto; kotieläintieteen laitos, 00710 Helsinki 71

Kahdessa kokeessa selvitettiin puumelassilla säilötyn ohran vaikutusta rehuannoksen sulavuuteen ja typen hyvăksikäyttőőn (koe 1 ja 2). Kokeessa 2 selvitettiin lisăksi vaikutusta pötsifermentaatioon ja rehun hajoamisnopeuteen pötsissă. Koe-elăimet saivat kuiva-ainetta $0.9 \mathrm{~kg} / \mathrm{pv}$, josta heinăn osuus oli kokeessa $130 \%$ ja kokeessa $240 \%$. Koerehuina oli kokeessa 1 kuivattu (KO), sekä 8 (PMO8) ja $16 \%$ :n puumelassilisäyksellă săilötty ohra (PMO16) sekä kokeessa 2 kuivattu (KO), propionihapolla jyvåsăilötty (PrO), AIV II:Ila (AIV2O) tai puumelassilla (12\% ohran ka:sta) săilötty ohra (PMO12).

Puumelassitason noustessa rehuannoksen sulavuus huononi. Ero oli merkitsevă $(\mathrm{P}<0.05)$ KO:n ja PMO16:n kuiva-aineen ja orgaanisen aineen sulavuudessa. Puumelassilla säilötty ohra huononsi hieman raakavalkuaisen ja raakakuidun năennäistă sulavuutta ja lisăsi typen pidăttymistă $(\mathrm{P}>0.05)$. Pidăttyneen typen osuus typen saannista oli kokeessa 1 KO-, PMO8- ja PMO16-ruokinnalla 13.1, 17.8 ja $15.8 \%$ sekă kokeessa 2 KO-, PrO-, AIV2O- ja PMO12- ruokinnalla 13.8, $13.2,10.3$ ja $14.5 \%$ vastaavasti.

KO- ja PrO-ruokinnalla pötsinesteen $\mathrm{pH}$ laski ja VFA-pitoisuus nousi văhemmăn kuin murskesăilőtyillă viljoilla. Propionihapon osuus VFA:sta oli KO- ja PrOruokinnalla korkeampi $(\mathrm{P}<0.01)$ ja voihapon osuus KO-ruokinnalla alempi $(\mathrm{P}<0.01)$ kuin AIV2O- ja PMO12-ruokinnalla. Murskesäilöttyä ohraa käytettăessă pitkäketjuisten rasvahappojen osuus VFA:sta lisaaăntyi. KO- ja PrO-ruokinnalla pötsinesteen ammoniakkipitoisuus alkoi laskea ruokinnan jälkeen, mutta AIV2O- ja PMO12-ruokinnalla ammoniakkihuippu saavutettiin 1.5 tuntia ruokinnan jälkeen. Murskesăilöntă lisăsi sekă kuiva-aineen ettă raakavalkuaisen hajoamisnopeutta pötsissă nailonpussimenetelmăllă mäăritettynä. 